\title{
Seasonal Changes of the Bottom Sediments' Physicochemical Characteristics in the Region of the Near-Coastal Methane Seeps
}

\author{
K. I. Gurov*, M. A. Myslina, S. K. Konovalov \\ Marine Hydrophysical Institute, Russian Academy of Sciences, Sevastopol, Russian Federation \\ *e-mail: gurovki@gmail.com
}

\begin{abstract}
The features of seasonal changes in physical (moisture, granulometric composition) and chemical (organic carbon content and carbonate content) characteristics of the bottom sediments in the region of the coastal methane seeps in the southern sector of the Tarkhankut Peninsula are investigated. It is shown that the bottom sediments of the region under study are represented by fine- and mediumgrained sand containing inclusions of aleurite-pelitic silts and shell detritus. The obtained in situ data on the content and vertical distribution of $\mathrm{C}_{\text {org }}$ and $\mathrm{CaCO}_{3}$ in the bottom sediments make it possible to examine the intra-annual dynamics of the basic geochemical parameters in the areas of the methane gas hydrates and to assess influence of the methane seeps upon the geochemical structure of the bottom sediments. The values obtained for the period under investigation can be divided into three parts: before formation of the bacterial mass (May), the period of maximum formation of mat (June - September), the time of destruction of the mat structures (November). It is shown that in May before the mat structures are formed, the $\mathrm{C}_{\text {org }}$ content in the surface $0-2 \mathrm{~cm}$ layer is low $(0.5 \%)$, in June it increases up to $15.5 \%$, then decreases to $9.7 \%$ in September and to $2.3 \%$ in November. In the surface layer, the $\mathrm{CaCO}_{3}$ content is maximal in late May (93.5\%); during the mat formation in June it decreases to $16.6 \%$ and then grows from 23.5 to $49.1 \%$ in August - November, respectively. Being analyzed, the data on vertical distribution of the geochemical characteristics under study show that accumulations of the bacterial mats affect the intra-annual variation of the above-mentioned parameters.
\end{abstract}

Keywords: Crimea, Tarkhankut peninsula, methane seeps, bottom sediments, granulometric composition, organic carbon, carbonate content.

Acknowledgements. The work is carried out with a financial support of RFBR grant No.16-05-00471 A.

For citation: Gurov, K.I., Myslina, M.A. and Konovalov, S.K., 2018. Seasonal Changes of the Bottom Sediments' Physicochemical Characteristics in the Region of the Near-Coastal Methane Seeps. Physical Oceanography, [e-journal] 25(2), pp. 136-143. doi:10.22449/1573-160X-2018-2-136-143

DOI: $10.22449 / 1573-160 \mathrm{X}-2018-2-136-143$

(C) 2018, K. I. Gurov, M. A. Myslina, S. K. Konovalov

(C) 2018, Physical Oceanography

Introduction. Until recently, the studies of methane in the marine environment were mostly aimed at studying the questions relating to the methane itself and the physical effect of its intake on thermochaline characteristics and exchange processes [1-3] but not on biogeochemical ones [4]. The main research areas on this theme are the following: the assessment of the gas emission intensity and the possibility of gas hydrates formation, the obtaining of quantitative estimates of the methane propagation during its dissolution in the water and its release into the atmosphere, as well as microbiological research aimed at studying the features of microbial consortia functioning within the framework of studying the methane cycles in the seawater [3].

Moreover, the research of methane seeps in the Black Sea was carried out mostly at the areas of continental slope and in the deepwater zones [2], i.e. at the depths of stable existence of gas hydrates and anaerobic processes. The study of methane cycle processes in the coastal area was significantly restricted by the re- 
search of its production in the surface layer of bottom sediments with high organic carbon $\left(\mathrm{C}_{\text {org }}\right)$ content and anaerobic oxidation at the boundary of bottom sediments and water. The study of jet gas emissions in the coastal area was started only in the last decade and the results of these studies are poorly presented in publications [5-7].

The first microbiological studies of methane seeps were carried out by the scientists of the Research Center of Biotechnology RAS (Moscow) and Institute of Marine Biological Research of RAS (IMBR) in December 1990 [8]. Later, in [9] it was shown that the carbonate buildups in the anaerobic zone at the gas seep sites are covered from the outside by a dense bacterial mat. This indicates the involvement of microorganisms into the geochemical processes of methane cycle $[10,11]$. In later works $[12,13]$ it was shown that the carbon of the methane itself, bacterial mat and carbonate buildups, formed as a result of anaerobic oxidation of methane, is characterized by high content of light carbon isotope.

Jet emissions of methane are the source of $\mathrm{C}_{\text {org }}$ in the marine environment; its input is a source of energy for various biogeochemical processes. In this case organic and inorganic carbons are the products of methane bacterial oxidation in aerobic (due to the oxygen) and anaerobic (during the sulfate reduction) conditions. Granulometric composition and water content of bottom sediments determine the intensity of physical fluxes and exchange between the bottom sediments and the bottom layer of water.

The purpose of the work is to estimate the impact of methane seeps on geochemical structure of bottom sediments and their intra-annual changes related to the processes of aerobic and anaerobic assimilation in the marine environment.

Materials and methods. The Tarkhankut Cape area under study is the open part of the Black Sea where direct sources of anthropogenic pollution are absent. In the coastal part of the studying region seasonal changes of physical and chemical characteristics of bottom sediments are greatly affected by hydrodynamic factors. In winter and spring they contribute to complete destruction of mats and saturation of the bottom layer with oxygen. In summer and autumn biochemical processes of sulfate reduction play a key role [14].

In the Tarkhankut Cape area there is a predominance of north-eastern storm winds directed from the shore and southern ones directed to the shore. The performed analysis of data over 1945-2008 given in [15] revealed the fact that the frequency of winds with $>10 \mathrm{~m} / \mathrm{s}$ speed for all the directions is $\sim 5 \%$. The winds of the southern, western and south-western rhumbs with $>10 \mathrm{~m} / \mathrm{s}$ speed are observed, on average, in $1.1 \%$ of cases during the year, with $>15 \mathrm{~m} / \mathrm{s}$ speeds - in $0.25 \%$ of cases. The maximum values of frequencies of winds with $>10 \mathrm{~m} / \mathrm{s}$ speed are recorded in January and February, in summer months their frequency is rather low.

Abrasion rate of the Tarkhankut limestone shores and benches does not exceed several centimeters per year, therefore the beaches here are small in volume and they stay under conditions of sharp deficit of sediments. Exposure to intensive wave processing during the storms contributes to good sorting of sediments [16].

The samples for studying physical and chemical characteristics of the bottom sediments, the features of their spatial distribution and the vertical structure were taken during complex in situ studies in the area of coastal jet emissions of methane in the northwestern part of the Crimean Peninsula (Okunevka, Chernomorskiy district) (Fig. 1). The work [17] is devoted to the study coastal methane seeps in this PHYSICAL OCEANOGRAPHY VOL. 25 NO. 22018 
region. Currently, $\sim 7$ coastal methane seeps along $10 \mathrm{~km}$ coastline are found. The areas of methane seepage make up 5-143 $\mathrm{m}^{2}$. The studied filtering area reaches $20 \mathrm{~m}$ in diameter and is located about $50 \mathrm{~m}$ from the shore at $\sim 5 \mathrm{~m}$ depth. Expeditions were performed in different seasons: in spring (May), in summer (June, August) and in autumn (September, November). Methane emissions were observed during the entire period of research from April to November 2016.

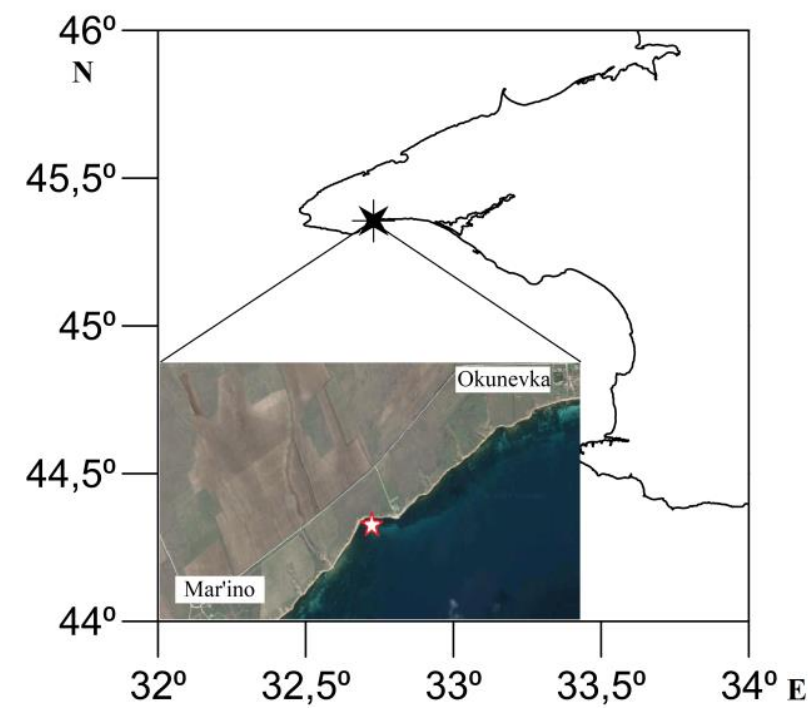

Fig. 1. Location of the studied Crimean Peninsula shelf area

Selection and preparation of bottom sediment samples were carried out in accordance with regulatory documents.

Natural water content was determined gravimetrically according to standard procedures (GOST R ISO 11465-2011; introduced since 01.01.2013). The calculation of the water content in the samples was taken as the ratio of the difference between the wet and dry deposits to the wet deposit, taken in percentage. Grain size analysis was carried out by the standard method (GOST 12536-2014; introduced since 01.07.2015) according to recommendations given in [18]. Separation of aleurite-pelitic fraction $(\leq 0.05 \mathrm{~mm})$ was performed by wet screening method. Coarse fractions $(>0.05 \mathrm{~mm})$ were separated by sieving method after the drying.

Carbonate $\left(\mathrm{CaCO}_{3}\right)$ content in a sample was determined by volumetric weight method after the decomposition of carbonates with hydrochloric acid, taking into account the methodological recommendations of UNEP manual. As a result of repeated analysis of samples with an average value of $\mathrm{CaCO} 6.84 \%$, an average square deviation of $\pm 0.18 \%$ (variation coefficient 2.6\%) was obtained (UNEP/IOC/IAEA - 1995).

$\mathrm{C}_{\text {org }}$ concentration in the sample was determined by the spectrophotometric method after organic substance oxidation with a sulfochromic mixture (GOST 26213-91; introduced since 30.06.1993). An improved modification of the chemical analysis methodology was applied. 
The measurement of organic carbon and carbonate content was carried out twice in each sample; the mean value of the two measurements was used as measured parameters ( $\mathrm{C}_{\text {org }}$ and carbonate content $)$.

Repeatability of $\mathrm{C}_{\text {org }}$ content determination (carried out as two separated but consecutive measurements) results should not exceed $0.1 \%$ at $\mathrm{C}_{\text {org }}$ content up to $1 \%$ and $6.5 \%$ - at more than $1 \% \mathrm{C}_{\text {org }}$ content. Relative error of the method at up to $3 \%$ $\mathrm{C}_{\text {org }}$ content in the bottom sediments makes up 20\%, at 3-5\% content the permissible deviations are $15 \%$, more than $5 \%$ of $\mathrm{C}_{\text {org }}-10 \%$.

Results and discussion. Bottom sediments of the studied area are represented by fine and medium-grained sands with inclusions of aleurite-pelitic silts and shell detritus. The content of sand fraction $(1-0.1 \mathrm{~mm})$ varies vertically within $85-93 \%$ range (Fig. 2). Gravel material content (10-1 mm fraction) varies within $0.4-1.1 \%$ range. The presence of a finely dispersed fraction $(<0.1 \mathrm{~mm})$ is noted in $0-4 \mathrm{~cm}$ surface layer. In May its content reaches its maximum values $(14.3 \%)$ in the $2-4 \mathrm{~cm}$ layer, then it decreases with depth down to $2.9 \%$ in 6-8 cm layer. It is shown that the proportion of aleurite-pelitic material in 0-5 cm surface layer decreased from May to September down to $0.6 \%$, which is explained by the removal of finely dispersed material from the coastal zone.

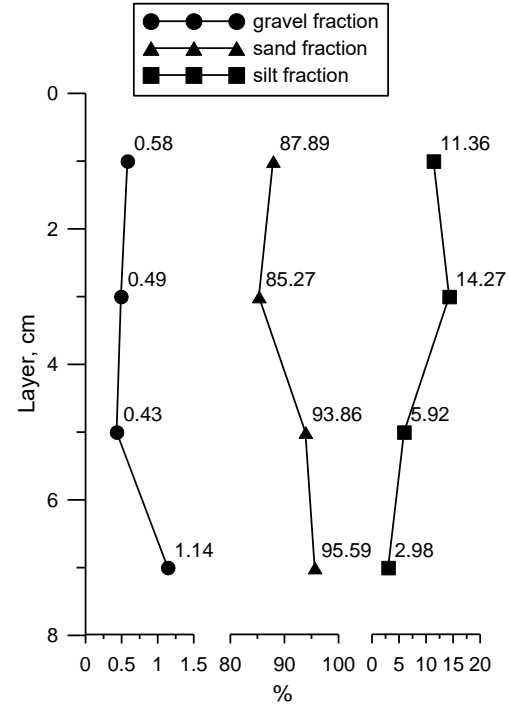

Fig. 2. Grain-size composition of bottom sediments of the studied area, May 2017

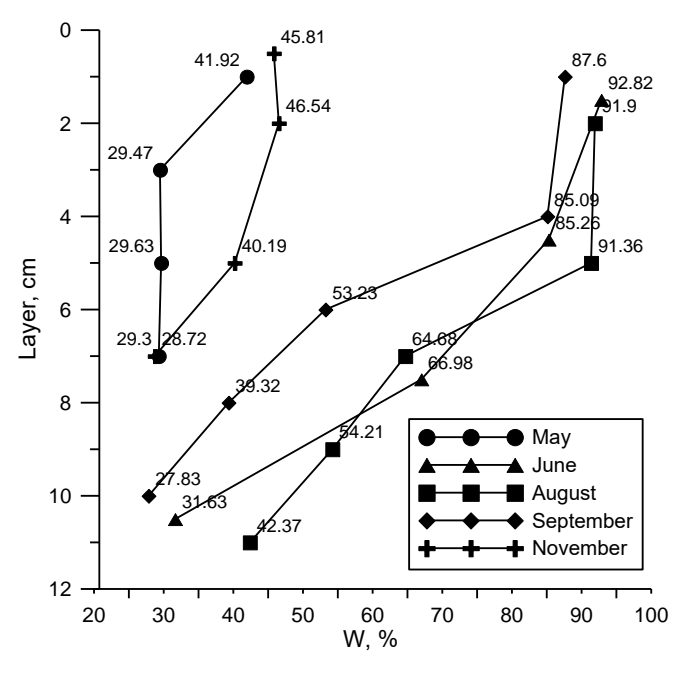

Fig. 3. Intra-annual variability of the vertical distribution of relative water content in the bottom sediment samples

The analysis of data of natural water content vertical distribution (Fig. 3) revealed that fractional composition of sediment and its formation under effect of hydrodynamic factors play a key role in the vertical structure of water content profile. The period under study can be divided into three seasons. In spring the water content maximum value makes up $42 \%$ in the surface layer where the maximum content of slit fraction is observed (average over the profile $-33 \%$ ). In summer, during the period of the maximum formation of bacterial mat an increase of water 
content takes place: in June $-93 \%$, in August $-92 \%$. In autumn, a reduction of water content values begins. In September in 0-3 cm surface layer they make up $87 \%$, in November they drop down to the level of the spring values ( $46 \%$ in $0-4 \mathrm{~cm}$ layer).

New in situ data on the vertical distribution of $\mathrm{C}_{\text {org }}$ and $\mathrm{CaCO}_{3}$ values in the bottom sediments made it possible to study the intra-annual dynamics of the main geochemical characteristics in the areas of methane jet emissions and to assess the impact of mat structures on it. In June and August a comparison of profiles of $\mathrm{C}_{\text {org }}$ and $\mathrm{CaCO}_{3}$ content in the bottom sediments was carried out for the samples taken in the central part of the mat and on its periphery.

Intra-annual variability in $\mathrm{C}_{\text {org }}$ vertical distribution (Fig. 4) can be correlated with three stages of geochemical characteristics: before the formation of bacterial mass (May), the period of the maximum bacterial mat formation (June - September), the period of mat buildups destruction (November).

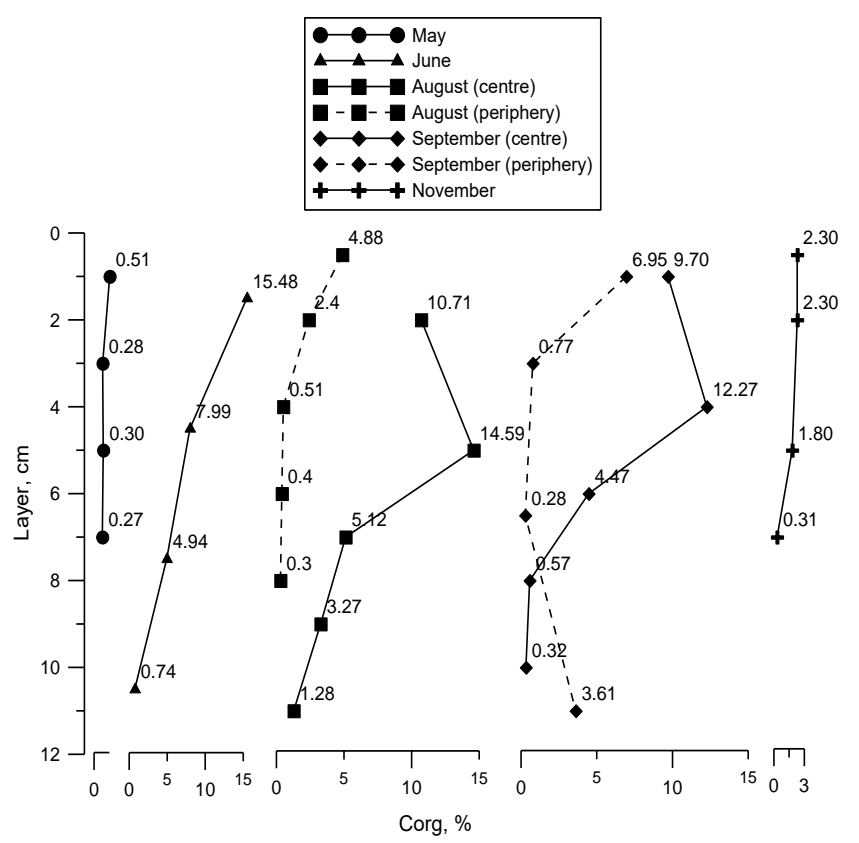

Fig. 4. Intra-annual variability of $\mathrm{C}_{\text {org }}$ vertical distribution in the bottom sediment samples

It is shown that $\mathrm{C}_{\text {org }}$ content in $0-2 \mathrm{~cm}$ surface layer before the formation of mat structures in May is low $(0.5 \%)$, in June it increases up to $15.5 \%$ and then it decreases down to $9.7 \%$ in September and $2.3 \%$ in November. The character of vertical distribution of the obtained characteristics persists throughout the year and the value of $\mathrm{C}_{\text {org }}$ content decreases with depth. The results obtained in August and September showed that there are cases when the maximum values of $\mathrm{C}_{\text {org }}$ content are noted in the subsurface layer. Such features are explained, on the one hand, by the processes of organic matter removal during storms, on the other - by its more intensive consumption and less intensive production.

The analysis of samples taken in the central part of the mat and on its periphery revealed the fact that the obtained quantitative characteristics of $\mathrm{C}_{\text {org }}$ content have a number of differences. It is shown that in August in the central part of the 140

PHYSICAL OCEANOGRAPHY VOL. 25 NO. 22018 
mat the maximum concentrations of $\mathrm{C}_{\text {org }}$ samples are $14.6 \%$ and they are found in 4-6 cm subsurface layer, $10.7 \%$ - in 0-4 cm layer; in September $12.3 \%$-in 3-5 cm layer, $9.7 \%-$ in $0-3 \mathrm{~cm}$ layer. On the periphery $\mathrm{C}_{\text {org }}$ content is maximal in $0-1 \mathrm{~cm}$ layer in August (4.9\%) and in 0-2 cm layer in September (6.9\%). The values of organic carbon concentration with the distance from the central part to the periphery significantly decrease with depth. In the surface layer they differ by two times and from 3-5 cm layer - by an order of magnitude.

In the vertical structure of sample taken on the periphery in September two layers of mat are found. During the storm surface layer of mat is covered with sand on which new bacterial constructions occur. Two-step formation of mat occurs in this way. Vertical distribution of $\mathrm{C}_{\text {org }}$ concentrations increases (from $0.3 \%$ in 4 $9 \mathrm{~cm}$ layer to $3.6 \%$ in $9-13 \mathrm{~cm}$ layer), the one of $\mathrm{CaCO}_{3}$ - decreases at that (from 97.8 to $46.1 \%$ in the same layers).

$\mathrm{CaCO}_{3}$ content in the surface layer is maximal in the end of May (93.5\%). It decreases in June (16.6\%) during the mat formation period and then increases from August to November from 23.5 to $49.1 \%$, respectively (Fig. 5). Inorganic carbon content in the sediments has an inverse relation to the organic carbon content (Fig. 6).

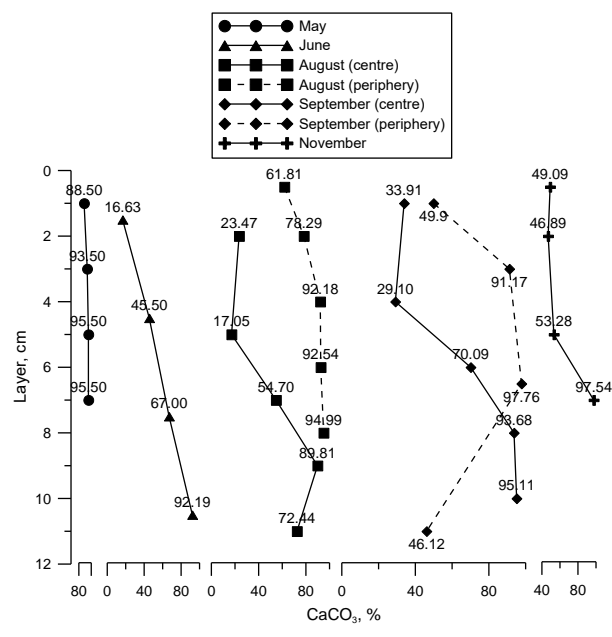

Fig. 5. Intra-annual variability of $\mathrm{CaCO}_{3}$ vertical distribution in the bottom sediment samples

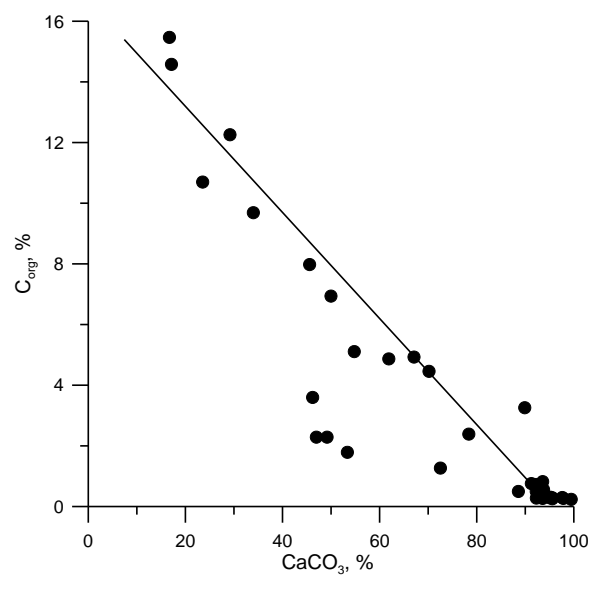

Fig. 6. $\mathrm{C}_{\text {org }}$ и $\mathrm{CaCO}_{3}$ concentration ratio in the bottom sediment samples

A comparison of concentrations in the central part of the mat and on the periphery showed that on the mat periphery carbonate content profile aligns from $0-2 \mathrm{~cm}$ layer ( $91 \%$ and higher), while in the central part similar values were recorded below $8 \mathrm{~cm}$.

Conclusions. Based on the latest data from field observations, the results of the study of the intra-annual dynamics of the main physical and chemical characteristics of bottom sediments in the area of coastal methane seeps were obtained. This is the uniqueness of the work.

Bottom sediments of the studied area are represented mainly by light yellow and grey sands with shell detritus inclusions, coarse material content varies within 0.4 $1.1 \%$ range and in the surface layers the presence of slits is determined. $\mathrm{C}_{\text {org }}$ content increases from $0.5 \%$ in May to $15.5 \%$ in June and then it decreases again down to 
$2.3 \%$ in November. It is shown that bacterial mass formation begins in May after the formation of stable vertical stratification of water column; the maximum is reached in August - September when the greatest bacterial biomass and the highest values of dissolved sulfide concentration are observed. Later, when the storm season comes, destruction and degradation of bacterial biomass layers takes place, and the processes of methane aerobic oxidation are replaced by anaerobic ones.

It is shown how the features of formation of clumps of anaerobic bacterial mats in different seasons affect the intensity of $\mathrm{C}_{\text {org }}$ and hydrogen sulfide production at the methane assimilation.

\section{REFERENCES}

1. Reeburgh, W.S., 2007. Oceanic Methane Biogeochemistry. Chem. Rev., [e-journal] 107(2), pp. 486-513. doi:10.1021/cr050362v

2. Egorov, V.N., Artemov, Yu.G. and Gulin, S.B., 2011. Metanovye Sipy v Chernom more Sredoobrazuyushchaya i Ekologicheskaya Rol' [Methane Seeps in the Black Sea: Environment-forming and Ecological Role]. Sevastopol: ECOSI-Gidrofizika, 405 p. (in Russian).

3. Lein, A.Yu. and Ivanov, M.V., 2009. Biogeokhimicheskiy Tsikl Metana v Okeane [Methane Biogeochemical Cycle in the Ocean]. Moscow: Nauka, 575 p. (in Russian).

4. Gurov, K.I., Myslina, M.A. and Konovalov, S.K., 2017. Osobennosti Sezonnoy Izmenchivosti Osnovnykh Fiziko-khimicheskikh Kharakteristik Donnykh Otlozheniy v Rayone Pribrezhnykh Struynykh Gazovydeleniy [Features of Seasonal Variability of the Main Physical and Chemical Characteristics of Bottom Sediments in the Area of Coastal Methane Seeps]. In: Tezisy X Vserossiyskoy Nauchno-prakticheskoy Konferentsii Molodykh Uchenykh po Problemam Vodnykh Ekosistem (11-16 sentyabrya 2017) [Abstracts of the $X^{\text {th }}$ All-Russian Scientific and Practical Conference of Young Scientists on the Problems of Water Ecosystems (September 11-16, 2017)]. pp. 70-73 (in Russian).

5. Egorov, V.N., Pimenov, N.V., Malakhova, T.V., Artemov, Yu.G., Kanapatsky, T.A. and Malakhova, L.V., 2012. Biogeokhimicheskie Kharakteristiki Raspredeleniya Metana v Vode i Donnykh Osadkakh v Mestakh Struynykh Gazovydeleniy v Akvatorii Sevastopol'skikh Bukht [Biogeochemical Characteristics of Methane Distribution in Sediment and Water at the Gas Seepage Site of Sevastopol Bays]. Marine Ecological Journal, 11(3), pp. 41-52 (in Russian).

6. Pimenov, N.V., Egorov, V.N., Kanapatsii, T.A., Malakhova, T.V., Artemov, Yu.G., Sigalevich, P.A. and Malakhova, L.V., 2013. Sulfate Reduction and Microbial Processes of the Methane Cycle in the Sediments of the Sevastopol Bay. Microbiology, [e-journal] 82(5), pp. 618624. doi: 10.1134/S002626171

7. Malakhova, L.V., Egorov, V.N., Malakhova, T.V., Gulin, S.B. and Artemov, Yu.G., 2010. Methane in the Sevastopol Coastal Area, Black Sea. Geo-Mar. Let., [e-journal] 30(3-4), pp. 391-398. doi:10.1007/s00367-010-0198-7

8. Ivanov, M.V., Polikarpov, G.G., Lein, A.Yu., Gal'chenko, V.F., Yegorov, V.N., Gulin, S.B., Gulin, M.B., Rusanov, I.I., Miller, Yu.M. and Kuptsov, V.I., 1991. Biogeokhimiya Tsikla Ugleroda v Rayone Metanovykh Gazovydeleniy Chernogo Morya [Biogeochemistry of Carbonic Cycle in the Region of Methane Ras Emission in the Black Sea]. Doklady AN SSSR, 320(5), pp. 1235-1240 (in Russian).

9. Gulin, S.B., Greinert, J., Egorov, V.N., De Batist, M. and Artemov, Yu.G., 2005. Observation of Microbial Carbonate Build-Ups Growing at Methane Seeps near the Upper Boundary of the Gas-Hydrate Stability Zone in the Black Sea. Marine Ecological Journal, 4(3), pp. 5-14.

10. Rusanov, I.I., Gal'chenko, V.F., Pimenov, N.V. and Ivanov, M.B., 1994. Mikrobiologicheskie Protsessy Tsikla Ugleroda v Rayone Chernomorskogo Metanovogo Sipa [Microbial Processes of Carbon Cycle in the Black Sea Methane Seepage Area]. Mikrobiologiya, 63(5), pp. 890895 (in Russian).

11. Pimenov, N.V., Rusanov, I.I., Poglazova, M.N., Mityushina, L.L., Sorokin, D.Yu., Khmelenina, V.N. and Trotsenko, Yu.A., 1997. Bacterial Mats on Coral-like Structures at Methane Seeps in the Black Sea. Microbiology, 66(3), pp. 354-361. 
12. Lein, A.Yu., Ivanov, M.V., Pimenov, N.V. and Gulin, M.B., 2002. Geochemical Peculiarities of the Carbonate Constructions Formed during Microbial Oxidation of Methane under Anaerobic Conditions. Microbiology, 71(1), pp. 78-90. doi:10.1023/A:1017906501726

13. Michaelis, W., Seifert, R., Nauhaus, K., Treude, T., Thiel, V., Blumenberg, M., Knittel, K., Gieseke, A., Peterknecht, K. [et al.], 2002. Microbial Reefs in the Black Sea Fueled by Anaerobic Oxidation of Methane. Science, [e-journal] 297(5583), pp. 1013-1015. doi:10.1126/science.1072502

14. Orekhova, N.A., Konovalov, S.K. and Ovsyaniy, E.I., 2013. Izmenenie Geokhimicheskikh Kharakteristik v Donnykh Osadkakh Krymskogo Poberezh'ya [Variation of Geochemical Characteristics in the Bottom Sediments of Crimean Coast]. In: MHI NANU, 2013. Ekologicheskaya Bezopasnost' Pribrezhnykh i Shel'fovykh Zon i Kompleksnoe Ispol'zovanie Resursov Shel'fa [Ecological Safety of Coastal and Shelf Zones and Comprehensive Use of Shelf Resources]. ECOSI-Gidrofizika. Iss. 27, pp. 284-288 (in Russian).

15. Goryachkin, Yu. N. and Repetin, L.N., 2009. Shtormovoy Vetro-Volnovoy Rezhim u Chernomorskogo Poberezh'ya Kryma [Storm Wind and Wave Regime near the Black Sea Coast of Crimea]. In: MHI NANU, 2009. Ekologicheskaya Bezopasnost' Pribrezhnykh i Shel'fovykh Zon i Kompleksnoe Ispol'zovanie Resursov Shel'fa [Ecological Safety of Coastal and Shelf Zones and Comprehensive Use of Shelf Resources]. ECOSI-Gidrofizika. Iss. 19, pp. 56-69 (in Russian).

16. Shuyskiy, Yu.D., 2007. Mekhanicheskiy Sostav Plyazhevykh Nanosov na Zapadnykh Beregakh Krymskogo Poluostrova [Mechanical Composition of Beach Alluvium on West Coast of the Crimea]. In: MHI NANU, 2007. Ekologicheskaya Bezopasnost' Pribrezhnykh $i$ Shel'fovykh Zon i Kompleksnoe Ispol'zovanie Resursov Shel'fa [Ecological Safety of Coastal and Shelf Zones and Comprehensive Use of Shelf Resources]. ECOSI-Gidrofizika. Iss. 15, pp. 370-385 (in Russian).

17. Gulin, M.B., 2004. Dependence of Location and Intensity of the Methane Cold Seeps on Geophysical Factors: the Black Sea Near-Shore Shallow-Water Seeps, Underwater Video-Materials. Geophys. Res. Abstracts, 6, 05394. Available at: http://www.cosis.net/members/meetings/abstracts/file.php/13/34982/jpdf/EGU04-J-05394.pdf [Accessed 20 October 2017].

18. Petelin, V.P., 1967. Granulometricheskiy Analiz, Morskikh Donnykh Osadkov [Granulametric Analysis of Marine Bottom Sediments]. Moscow: Nauka, 128 p. (in Russian).

\section{About the authors:}

Konstantin I. Gurov - Senior Engineer-Researcher, Marine Biogeochemistry Department, FSBSI MHI (2, Kapitanskaya Str., Sevastopol, 299011, Russian Federation), ORCID ID: 0000-00033460-9650, ResearcherID: L-7895-2017, gurovki@gmail.com

Maria A. Myslina - Senior Engineer-Researcher, Marine Biogeochemistry Department, FSBSI MHI (2, Kapitanskaya Str., Sevastopol, 299011, Russian Federation), ORCID ID: 0000-0002-00540379, ResearcherID: G-1442-2018, myslina@ mhi-ras.ru

Sergey K. Konovalov - Director, FSBSI MHI (2, Kapitanskaya Str., Sevastopol, 299011, Russian Federation), Dr.Sci. (Geogr.), Corresponding Member of RAS, ORCID ID: 0000-0002-52008448, ResearcherID: F-9047-2014, sergey_konovalov@yahoo.com

\section{Contribution of the co-authors:}

Konstantin I. Gurov - analysis of literature data, analysis and preparation of initial conclusions, qualitative analysis of the results and their interpretation

Maria A. Myslina - collection and systematization of data, processing and description of the research results

Sergey K. Konovalov - general scientific supervision of the research, formulation of goals and objectives of the research, analysis of materials in domestic and foreign sources on the research theme

All the authors have read and approved the final manuscript.

The authors declare that they have no conflict of interest. 